\title{
Structural Characteristics of Cr-Mo Steels Microalloyed with Cerium
}

Jaromír Drápala ${ }^{1}$, Pavel Machovčák ${ }^{2}$, Petr Jonšta ${ }^{2}$, Vu The Ha ${ }^{1}$, Silvie Brožová ${ }^{1}$, Gabriela Kostiuková1, Michal Madaj ${ }^{1}$ ${ }^{1}$ Vysoká škola báňská - Technical University of Ostrava, Faculty of Metallurgy and Materials Engineering, Regional Materials Science and Technology Centre, Av. 17. listopadu 15, 70833 Ostrava - Poruba, Czech Republic, E-mail: Jaromir.Drapala@vsb.cz, vutheha6@yahoo.com, Silvie.Brozova@vsb.cz, Gabriela.Kostiukova@vsb.cz, Michal.Madaj@vsb.cz,

${ }^{2}$ Vítkovice Heavy Machinery a.s., Ruská 2887/101, 70300 Ostrava - Vítkovice, Czech Republic, E-mail: pavel.machovcak@vitkovice.cz, petr.jonsta@vitkovice.cz

The results of an experimental study on influence of cerium addition on structural characteristics of $42 \mathrm{CrMo4}$ steel are presented. Alloying with cerium was carried out using profile filled with powdered mixture of mischmetal. The samples were taken from two ingots cast in the VHM's steelworks with standard time of casting of about 14 minutes. Three steel bars from one of the produced ingots were prepared by forging. Chemical composition, macro- and microstructure, X-ray EDX chemical microanalysis, hardness of the all steel samples were obtained. Cerium addition resulted in the formation of micrometer size inclusions which can be utilized for controlling the grain size structure of steel castings. The majority of the particles have settled at the bottom part of the casting, indicating that the convection flow during solidification was very weak. The cerium addition slightly diminished hardness of the steel. A segregation phenomenon causing inhomogeneous distribution of cerium over entire volume of as-cast samples after relatively rapid crystallization process of the steel was revealed.

Keywords: CrMo Steel, Cerium, Microstructure, Interaction, Microsegregation

\section{Acknowledgement}

This work was supported by project of the Technology Agency of the Czech Republic No. TA03010161 „Experimental development of non-ferrous metals utilization for microstructure refinement in the production of steel ingots for forgings in the specific works” and with the technical support of the Project No. LO1203 „Regional Materials Science and Technology Centre - Feasibility Program” and Project No. CZ.1.07/2.3.00/30.0016: „Opportunity for Young Researchers".

\section{References}

[1] GUO, M., SUITO, H. (1999). Influence of dissolved cerium and primary inclusion particles of $\mathrm{Ce}_{2} \mathrm{O}_{3}$ a $\mathrm{CeS}_{\text {on }}$ solidification behavior of Fe-0.20 mass \% C - 0.02 mass \% P plloy. ISIJ International, Vol. 39, No. 7, pp. 722729.

[2] IRONS, G.A., TONG, P, X. (1995). Treatment o steel with alkaline earth elements. ISIJ International, Vol. 35, No. 7, pp. 838-844.

[3] van der EIJK, INGROS, C. (2004). Final Technical Report. SINTEF Materials Technology, Trondheim, Norway, $77 \mathrm{pp}$.

[4] DAHLE, E.S. (2011). Grain refinement of high alloyed steel with cerium addition. Technical Report, Norwegian University of Science and Technology, $68 \mathrm{pp}$.

[5] ANDERSON, M. et al. (2011). Grain size control in steel by means of dispersed non-metallic inclusions GRAINCONT. Final Technical Report. Luxembourg, Publications Office of the European Union, 132 pp.

[6] BROŽOVÁ, S., DRÁPALA, J., MACHOVČÁK,P., JONŠTA,P., PUSTĚJOVSKÁ, P. (2014). Use of mischmetal to improve the properties of steels. Chapter in monograph, No. 42, Częstochowa, pp. 45-61, ISSN 2080-2072.

[7] DRÁPALA, J., BROŽOVÁ, S., MADAJ, M., VU THE HA, MACHOVČÁK, P., JONŠTA, P., VINŠ, M. (2014). Study of the interaction of mischmetal in special types of steels at crystallization processes. In: Proceedings of the $23^{\text {rd }}$ Conference METAL 2014, Brno, May $21^{\text {st }}-23^{\text {rd }}$, Brno, Ed. Tanger s.r.o., Ostrava, on CD ROM, pp. 139-147. ISBN 978-80-87294-54-3.

[8] JONŠTA, P., MACHOVČÁK, P., SUŠOVSKÝ, M., TREFIL, A., BROŽOVÁ, S., DRÁPALA, J. (2014). The influence of cerium on the microstructure optimization of $42 \mathrm{CrMo} 4$ steel. In: Proceedings of the $23^{\text {rd }}$ Conference METAL 2014, Brno, May $21^{\text {st }}-23^{\text {rd }}$, Brno, Ed. Tanger s.r.o., Ostrava, on CD ROM, pp. 564-568. ISBN 978-8087294-54-3.

[9] NOVÁK, M. (2011). Surface quality of hardened steels after grinding. Manufacturing Technology, Vol. 11, pp. 55-59.

[10] ROSENBERG, G., JUHAR, L. (2012). Fatigue resistance of dual phase steels in presence of microstructural inhomogeneities. Manufacturing Technology, Vol. 12, No. 13, pp. 217-221.

[11] KUNDRÁK, J. (2011). Alternative machining procedures of hardened steels. Manufacturing Technology, Vol. 11, No. 11, pp. 32-39. 